\title{
Effect of Inflammation on Molecular Targets and Drug Transporters
}

\author{
Sherif Hanafy, Ayman O.S. El-Kadi; Fakhreddin Jamali \\ Faculty of Pharmacy and Pharmaceutical Sciences, University of Alberta, Edmonton, Alberta, Canada
}

Received, April 25, 2012; Revised May 23, 2012; Accepted, May 24, 2012, Published May 31, 2012.

\begin{abstract}
Inflammation, the host's response to infection and injury, is associated with altered expression of genes such as metabolizing enzymes, transporters, receptors and plasma proteins. The purpose of the present work was to characterize the effect of inflammation on selected molecular targets and transporters that affect drugs' action and disposition. We have used rats with adjuvant arthritis (AA), an animal model of chronic inflammation. The AA group received $0.2 \mathrm{ml}$ of $50 \mathrm{mg} \mathrm{ml}^{-1}$ Mycobacterium butyricum suspended in squalene into the tail base. On day 12, the rats were euthanized and their organs (heart, liver, kidneys and intestine) excised. Expression of Cav1.2, $\beta 1-A R, \beta 2-A R, \alpha 1 \mathrm{~A}-\mathrm{AR}$, Nav1.2, Nav1.6, Kv1.5, Kv2.1, Kv3.1, oatp1a1, oatp1a5, oatp1b2, oatp2b1, oatp4a1, oat2, oat3, oct1, mdr1a, bsep, mrp1, mrp3, mrp6, IL-1 $\alpha$, IFN- $\gamma$, iNOS, MCP-1, IL-10, Cox-1 and Cox-2 were determined by real time polymerase chain reaction (RT-PCR). Inflammation resulted in a significant reduction of oct1, oatp4a1 and mrp1 gene expression in the liver and oatp2b1, mrp6 and bsep gene expression in the kidney. Oatp4a1 and mdrla were found to be significantly upregulated in rat heart. In conclusion, inflammation alters the gene expression of some mediators and drug transporters that can influence the behavior of drugs in the body and contribute to therapeutic failure.
\end{abstract}

This article is open to POST-PUBLICATION REVIEW. Registered readers (see "For Readers") may comment by clicking on ABSTRACT on the issue's contents page.

\section{INTRODUCTION}

Inflammation is the host's response to infection, injury or irritation. The development of the inflammatory response is a complex process that involves increased expression of chemicals such as cytokines and chemokines in a paracrine, autocrine, and/or endocrine fashion. This enhances the host's defense through immune cell recruitment and activation, antibody production and complement system activation [1]. The process has been found to be associated with altered expression of other genes either as a part of the host's defense mechanism or because of shifting priorities in the cellular expression machinery. Examples of the affected genes are metabolizing enzymes [2-4], transporters [5], receptors [6-10] and plasma proteins [11-13]. Inflammation-induced alterations of gene expression may be responsible, at least in part, for disease pathogenesis. For example, atrial fibrillation developed in septic shock patients $[14,15]$ has been attributed to inflammation-induced L-type calcium channel dysfunction [16]. In addition, animal and human studies have shown that inflammation is an important factor that may alter drug action and/or disposition [6,8,17-22]. Recently, we have reported that inflammation significantly downregulated angiotensin-converting enzyme-2 in rat heart, an observation that may contribute to the cardiovascular complications seen in inflammatory diseases [23]. The purpose of the present work was to investigate whether the effect of inflammation on target proteins goes beyond what has been reported earlier. We investigated the effect of inflammation on selected molecular targets and transporters that are known to be involved in the pharmacokinetics and pharmacodynamics of some drugs (Table 1). We have used rats with adjuvant arthritis (AA), an animal model of chronic inflammation that is known to mimic human rheumatoid arthritis [24].

Abbreviations. Cav1.2, $\alpha 1 \mathrm{c}$ subunit of L-type calcium channels; $\beta 1$-AR, $\beta 1$ adrenergic receptor, $\beta 2-A R, \beta 2$ adrenergic receptor; $\alpha 1 \mathrm{~A}-\mathrm{AR}, \alpha 1 \mathrm{~A}$ adrenergic receptor, $\mathrm{Nav}$, voltage-gated sodium channels; $\mathrm{Kv}$, voltage-gated potassium channels; 18s rRNA, 18s ribosomal RNA; oatp, organic anion transporter polypeptide; oat2, organic anion transporter; oct, organic cation transporter; mdr, multidrug resistance transporter; bsep, bile salts export pump; mrp, multidrug resistance-associated protein; IL, interleukin; IFN- $\gamma$, interferon $\gamma$; iNOS, inducible nitric oxide synthetase; MCP-1, monocyte chemoattractant protein 1; COX, cyclooxygenase; ACE, angiotensin converting enzyme.

Corresponding Author: Fakhreddin Jamali, Faculty of Pharmacy \& Pharmaceutical Sciences, 11361 - 87 Avenue, Edmonton, Alberta, Canada T6G 2E1; fjamali@ualberta.ca 
Table 1. The biological/clinical relevance of the tested drug transporters, adrenergic receptors, ion channels and select mediators

\begin{tabular}{l} 
Tested gene \\
\hline INFLUX TRANSPORTERS: \\
Oatp1a1 \\
Oatp1a5 \\
Oatp1b2 \\
Oatp2b1 \\
Oatp4a1 \\
Oat2 and oat3 \\
\\
Oct1 \\
EFFLUX TRANSPORTERS: \\
Mdr1a \\
Bsep
\end{tabular}

Mrp1 Biological/clinical relevance

Substrates: enalapril, indomethacin, PG E2 methotrexate, dexamethasone, cortisol, aldosterone, digoxin, T3, T4, Bile salts and pravastatin.

Substrates: Bile salts, methotrexate, digoxin, T3, T4 and fexofendine [66].

Substrates: T3, T4, digoxin, methotrexate and pravastatin [67]; The use of oatp1b2 knockout mice resulted in 4 and 8 -fold decrease of the liver to plasma ratio of pravastatin and rifampicin, respectively and a $43 \%$ reduction of rifampicin clearance [68]; Knockout animals are less sensitive to the hepatotoxic effects of some toxins due to their decreased uptake [67].

Substrates: PG F2 $\alpha$, PG E2 and digoxin [32].

One of the thyroid hormone transporters [34].

Oat2 Substrates: PG F2 $\alpha$, salicylate, PG E2, methotrexate, acetyl salicylate, cimetidine, and indomethacin; Oat3 substrates: Pravastatin, penicillin G, cimetidine; Downregulation of OATs or their inhibition has been found to result in a reduction of the renal clearance of their substrates. For example probencid administration, an OAT inhibitor, inhibits the renal excretion of penicillin G and ACE inhibitors and prolongs their half-lives[69]; The renal uptake of xenobiotics mediated by OATs has also been described as a means for nephrotoxins accumulation in the kidney and contribution to kidney failure [70].

Substrates: cytarabine, metformin, amantadine, quinine, quinidine, dopamine, pnacuronium, cimetidine, saquinavir and pramipexole.

Example substrates: quinidine, verapamil and octreotide.

BSEP is an efflux transporter located at the canalicular side of hepatocytes and is involved mainly in the hepatic secretion of bile salts[71]; It is involved in pravastatin[72] and vinblastine[73] transport.

MRP1 has been associated with the resistance of tumor cells to anticancer chemotherapy by reducing their cellular accumulation[74]; MRP1 plays a role in the pathogenesis of inflammation. Glutathione and its conjugates are transported by MRP1, as a part in the detoxification pathway of toxins [75]; Substrates: Vincristine, etoposide, doxorubicin, daunorubicin and $17 \beta$-estradiole conjugate.

Mrp3 Substrates: $17 \beta$ estradiole conjugate and methotrexate; Both MRP1 and MRP3 are localized on the basolateral side of hepatocytes and so they are responsible for the efflux of chemicals to the blood stream [76].

Mrp6

ION CHANNELS: $\mathrm{Ca}_{\mathbf{v}} 1.2$ MRP6 serves a housekeeping function in solute transport into bile [77]; MRP6 dysfunction has been implicated in the development of pseudoxanthoma elasticum, a genetic condition characterized by elastic fiber fragmentation and premature atherosclerosis [74]; Substrates: anthracyclines

L-type calcium channels are essential for coupling the membrane excitation to muscle contraction especially in cardiac muscles. In addition, calcium entry through those channels is responsible for neurotransmitter release, synaptic plasticity and gene expression $[78,79]$.

$\mathrm{Na}_{\mathrm{v}} 1.2$ and 1.6

$K_{v} 1.5,2.1$ and 3.1
They function in the action potential initiation and conduction. Both channels are actual and potential targets for antiepileptic drugs [80].

$\mathrm{Ka}_{\mathrm{v}} 1.5$, an ultra rapid delayed rectifier channel, plays a role in maintaining the membrane potential and excitability of neurons and cardiac muscles [81]. It is considered a potential target for treatment of atrial fibrillation; Potassium channels alterations have been implicated in human diseases. While, $\mathrm{K}_{\mathrm{v}} 1.5$ is downregulated in patients with atrial fibrillation [115], both $\mathrm{K}_{\mathrm{v}} 1.5$ and $\mathrm{K}_{\mathrm{v}} 2.1$ are downregulated in chronic pulmonary hypertension [116].

Table 1 continues: 
Table 1 continued.....

Adrenergic Receptors

OTHERS:

COX-1 and 2 Cyclooxygenases are important enzymes involved in the production of essential prostaglandins in all parts of the body.

IL-1a An in inflammatory mediator; Activates T-cells and macrophages; Implicated in the pathogenesis of RA, septic shock and atherosclerosis[82].

IFN- $\gamma$

iNOS

MCP-1

IL-10
Each receptor provides important physiological functions mediated by the sympathetic nervous system. They are considered the main site of action of many drugs that are clinically in use such as $\beta 1$ adrenoceptor and $\alpha 1$-blockers.

\section{MATERIALS AND METHODS}

\section{Experimental Protocol}

The study protocol was approved by the Health Sciences Animal Policy and Welfare Committee of the University of Alberta. Experiments were carried out on male Sprague-Dawley rats (220-280 g). They were housed in a temperature- controlled room with a 12-h dark/light cycle. Two animal groups ( $n=4 /$ group), inflamed (AA) and healthy (Control) were used.

The inflamed group received $0.2 \mathrm{ml}$ of 50 $\mathrm{mg} / \mathrm{ml}$ Mycobacterium butyricum suspended in squalene into the tail base. Control animals received an equal volume of normal saline into the tail base. On day 12, when inflammation emerged, i.e., increased paw diameter and elevated proinflammatory mediators [19], rats were euthanized and their organs (heart, liver, kidneys and upper intestine) were excised and quickly frozen in liquid nitrogen. The excised organs were stored at $-80^{\circ}$.

\section{Real Time Polymerase Chain Reaction (RT- PCR)}

To determine the potential genetic changes, RTPCR was carried out. Total RNA was isolated from the frozen organs using TRIzol reagent (Invitrogen, Carlsbad, CA, USA) according to the manufacturer's instructions. This was followed by spectrophotometric quantitation of the isolated RNA by measuring the absorbance at $260 \mathrm{~nm}$. cDNA was synthesized from $1.5 \mu \mathrm{g}$ total RNA samples with the random primers scheme using the High Capacity cDNA Reverse Transcription Kit (Applied Biosystems, Foster City, CA, USA). Real-Time PCR was performed on an ABI 7500 Real-Time PCR system (Foster City, CA, USA).
Forward and reverse primers used for the experiments are depicted in Table 2. The housekeeping gene tested was the rat 18s rRNA. Melting curves were carried out to confirm amplification of single sequences and absence of primer dimers. Primers were purchased from Integrated DNA technologies (Coralville, IA, USA). PCR products were produced and detected quantitatively using SYBR Green PCR Master Mix (Applied Biosystems, Foster City, CA, USA). PCR data were analyzed using the delta delta $\mathrm{C}_{\mathrm{T}}$ method $\left(\Delta \Delta \mathrm{C}_{\mathrm{T}}\right)$ as described by Livak and Schmittgen [25]. The data are expressed as fold change relative to a calibrator (Control) and normalized to the housekeeping gene.

\section{Data Analysis}

Data are expressed as mean \pm SD. Statistical significance between the control and AA groups was analyzed using a two-tailed Student's t-test at $p<0.05$. Statistics were analyzed using Prism software v. 4.03 (GraphPad Software, Inc., San Diego, CA, USA).

\section{RESULTS}

\section{Tested Genes in organs}

The constitutive expression of drug transporters, adrenergic receptors, voltage-gated ion channels and COX 1 and 2 genes was found to be tissue specific (Figures 1 and 2). Tissue distribution of drug transporters in the liver, kidney and intestine was found to be similar to what has been previously reported (Table 3 ). In addition, MCP-1 was detected in the organs of Control rats. 


\section{Effect of Inflammation on the Tested Genes' mRNA}

The influence of inflammation on the examined genes' mRNA in various organs is depicted in Figure 3.

Liver - Inflammation resulted in a significant reduction of oct1, oatp4a1 and mrp1 gene expression in the liver. There was also a general trend towards drug transporter downregulation in the liver except for mrp3 and mdr1a. The changes, however, were not statistically significant. There was no difference between AA and control animals with respect to $\mathrm{COX}-1, \mathrm{COX}-2$, ion channels and adrenergic receptors gene expression.
Kidney - Inflammation resulted in a significant reduction of oatp2b1, mrp6 and bsep gene expression in the kidney. On the other hand, oatp4a1 demonstrated a trend towards upregulation. $\mathrm{Na}_{\mathrm{v}} 1.2$ gene expression was significantly induced (up to four-fold) in inflamed animals. There was a general trend towards renal cytokine gene upregulation in AA animals. However, only the elevation of IFN- $\gamma$ was statistically significant. There was no difference between AA and control animals with respect to COX-1, COX-2, other ion channels and adrenergic receptors gene expression.

Table 2. List of primers used in real-time PCR

\begin{tabular}{|c|c|c|c|}
\hline Target & Forward Primer & Reverse Primer & Ref \\
\hline $\mathrm{Ca}_{\mathrm{v}} 1.2$ & AGCAACTTCCCTCAGACGTTTG & GCTTCTCATGGGACGGTGAT & {$[83,84]$} \\
\hline$\beta 1-\mathrm{AR}$ & CTGCTACAACGACCCCAAGTG & AACACCCGGAGGTACACGAA & {$[85]$} \\
\hline$\beta 2-A R$ & GAGCCACACGGGAATGACA & CCAGGACGATAACCGACATGA & [85] \\
\hline$\alpha_{1 \mathrm{~A}}-\mathrm{AR}$ & CGAATCCAGTGTCTTCGCAG & ACCATGTCTCTGTGCTGTCCC & [86] \\
\hline $\mathrm{Na}_{\mathrm{v}} 1.2$ & TCCGGTTTCGTCACGCTATC & TCCAGAGAAGACTGATGTGACACC & [87] \\
\hline $\mathrm{Na}_{\mathrm{v}} 1.6$ & CAAGCTGGAGAATGGAGGCA & TAAGAGGGGAGGGAGGCTGT & [87] \\
\hline $\mathrm{K}_{\mathrm{v}} 1.5$ & CGCACAACGCTCGAGGAT & CCTCAGCAGATAGCCTTCTAGGTT & [88] \\
\hline $\mathrm{K}_{\mathrm{v}} 2.1$ & ACGAGGGTCAGCTGCTCTACAG & TGCTGAACTTGGGACTGGTACTC & [88] \\
\hline $\mathrm{K}_{\mathrm{v}} 3.1$ & CACGCATCTGGGCACTGTT & TGAAGAAGAGGGAGGCAAAGG & [88] \\
\hline 18s rRNA & GGGAGGTAGTGACGAAAAATAACAAT & TTGCCCTCCAATGGATCCT & [89] \\
\hline Oatpla1 & ACCTGGAACAGCAGTATGGAAAA & ACCGATAGGCAAAATGCTAGGTAT & [90] \\
\hline Oatp1a5 & TGATGTGGATGGAACTAACAATGAC & TGCATTTATCTGGAGCACACTTG & [90] \\
\hline Oatp1b2 & CCTGTTCAAGTTCATAGAGCAGCA & TGCCATAGTAGGTATGGTTATAATTCCTAA & {$[90,91]$} \\
\hline Oatp2b1 & ACGACTTTGCCCACCATAGC & CCACGTAAAGGCGTAGCATGA & {$[90]$} \\
\hline Oatp4a1 & AGAACGTCAAGTCGAGCTATTCG & GGCCCACTTCTGTGTAAACATTT & {$[90]$} \\
\hline Oat2 & CGTGTGTCCCAGGCATCA & TCCACACGACCCTGGGTTAG & {$[90]$} \\
\hline Oat3 & GAGGACCTGTGATTGGAGAACTG & CTGGCTGCCAGCATGAGATA & [92] \\
\hline Oct1 & TGGTGTTCAGGCTGATGGAA & GCCCAAAACCCCAAACAAA & [93] \\
\hline Mdrla & GTGGGAAAAGCACAACTGTCC & CCATGGTGACGTTTTCTCGG & [90] \\
\hline Bsep & CACTGGGTACATGTGGTGTCTCAT & ATGGCCAATATTCATAGCTGCTAAT & {$[90]$} \\
\hline Mrp1 & CGAATGTCCTCTGAGATGGAGAC & CTCTACACGGCCTGAATGGG & [90] \\
\hline Mrp3 & TCTTTGTGATGGCCTTGAGGATA & TTGACCATTTCTCCCACAGTGT & [90] \\
\hline Mrp6 & GAAGACTCCAAGCCATTGAATCC & TCTCTCAAGTGACCAGAGGTCTTTT & {$[90]$} \\
\hline IL-1 $\alpha$ & AGGCATCCTCAGCAGCAGAA & AGCTCCACGGATGTGGAAAC & [94] \\
\hline IFN- $\gamma$ & GCCAAGTTCGAGGTGAACAAC & TAGATTCTGGTGACAGCTGGTGAA & {$[95]$} \\
\hline iNOS & TGGTCCAACCTGCAGGTCTT & CAGTAATGGCCGACCTGATGT & [96] \\
\hline MCP-1 & CTGTCTCAGCCAGATGCAGTTAA & TGGGATCATCTTGCCAGTGA & [95] \\
\hline IL-10 & GAAGCTGAAGACCCTCTGGATACA & CCTTTGTCTTGGAGCTTATTAAAATCA & [96] \\
\hline $\mathrm{COX}-1$ & TCCTGTTCCGAGCCCAGTT & CTTGGAAGGAATCAGGCATGA & [97] \\
\hline COX-2 & CCCCAAGGCACAAATATGATG & CCTCGCTTCTGATCTGTCTTGA & [97] \\
\hline
\end{tabular}

Primers were purchased from Integrated DNA Technologies (Coralville, IA, USA). Cav1.2, $\alpha$ 1c subunit of L-type calcium channels; $\beta 1$-AR, $\beta 1$ adrenergic receptor, $\beta 2$-AR, $\beta 2$ adrenergic receptor; $\alpha 1 \mathrm{~A}-\mathrm{AR}, \alpha 1 \mathrm{~A}$ adrenergic receptor, Nav, voltagegated sodium channels; Kv, voltage-gated potassium channels; 18s rRNA, 18s ribosomal RNA; oatp, organic anion transporter polypeptide; oat2, organic anion transporter; oct, organic cation transporter; mdr, multidrug resistance transporter; bsep, bile salts export pump; mrp, multidrug resistance-associated protein; IL, interleukin; IFN- $\gamma$, interferon $\gamma$; iNOS, inducible nitric oxide synthetase; MCP-1, monocyte chemoattractant protein 1; COX, cyclooxygenase. 

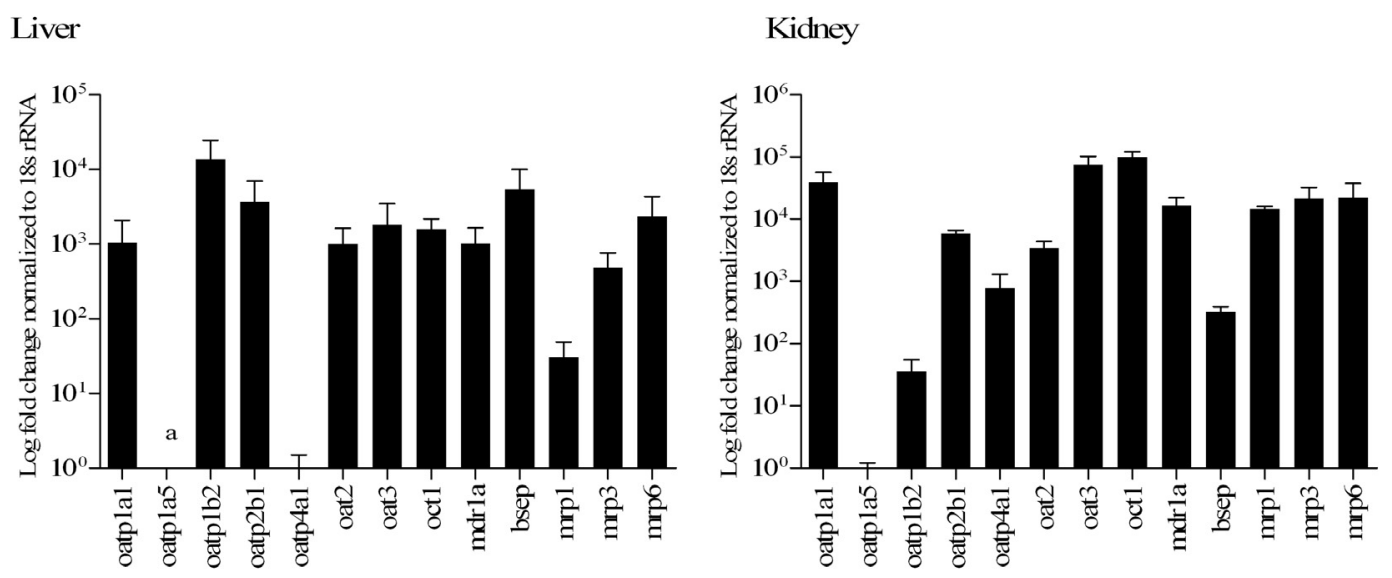

Heart

Intestine
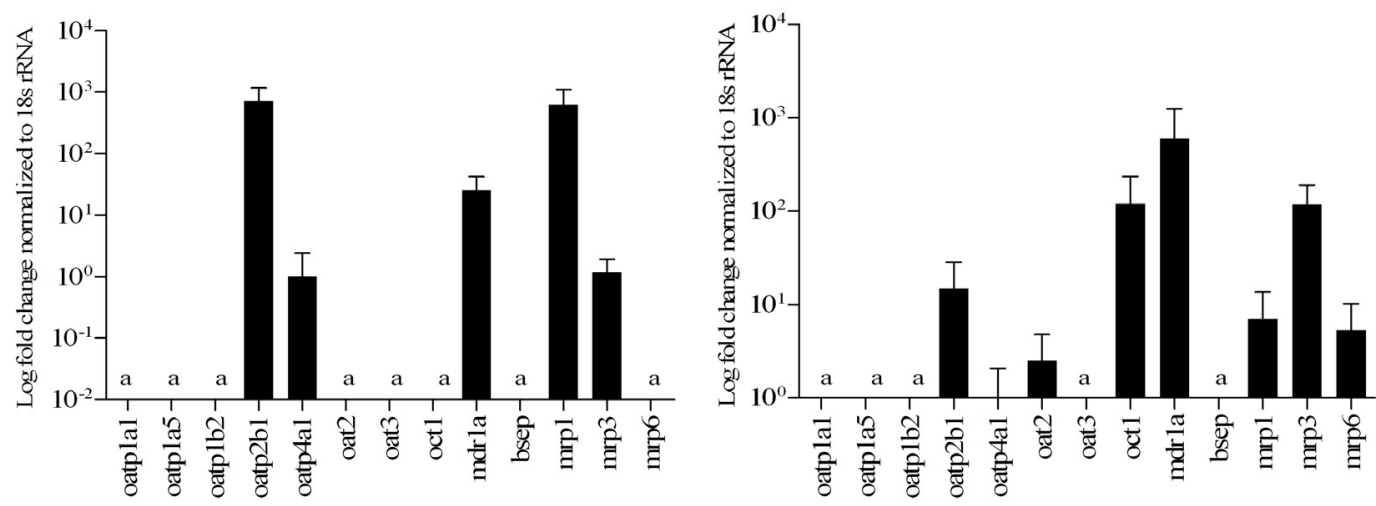

Figure 1. Constitutive expression of drug transporter genes in different rat organs ( $\mathrm{n}=4$ /group). Expression was determined using real time PCR in rat liver, kidney, heart and intestine. Gene expression was normalized to $18 \mathrm{~s}$ rRNA. Relative expression was determined relative to a calibrator, the gene with the lowest expression in each organ. a, was not detected in the organ.

Heart - Out of the detected transporters in the hearts of control animals, oatp4a1 and mdrla were found to be significantly increased by inflammation. Mrp3 was not detected in inflamed animals. Interestingly, despite being undetected in control animals, oatp1b2, oat2 and oat3 were detected in inflamed rats. There was no significant difference between AA and Control animals with respect to ion channels and adrenergic receptors gene expression. While not detectable in Control animals, COX-2 gene expression was detected in the AA group. On the other hand, inflammation significantly inhibited COX-1 gene expression.

Intestine - Due to the high variability observed in intestinal tissue, none of the tested genes were significantly different from the control. However, some transporters (such as oct1, mdrla and mrp3) showed a strong trend towards downregulation.

\section{DISCUSSION}

We used the AA model, which mimics human rheumatoid arthritis in terms of development of systemic inflammation and arthritis [24]. Six days following administration of the adjuvant, the inflammatory mediators start to rise [19] and in approximately 12 days, animals develop arthritis. This model allowed us to study the effect of chronic inflammation on the gene expression of drug transporters, adrenergic receptors, ion channels and select mediators of biological relevance (Table 1).

MCP-1 was present in all of the examined organs of healthy and AA rats and demonstrated a trend toward increased expression in the kidney and heart in response to inflammation. MCP-1 has previously been detected in rat interstitial fibroblasts [26] and smooth muscle cells [27], 


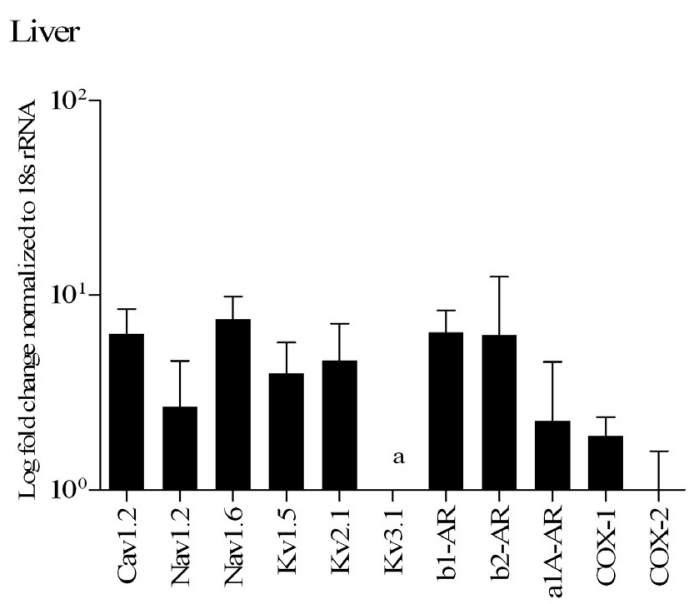

Kidney

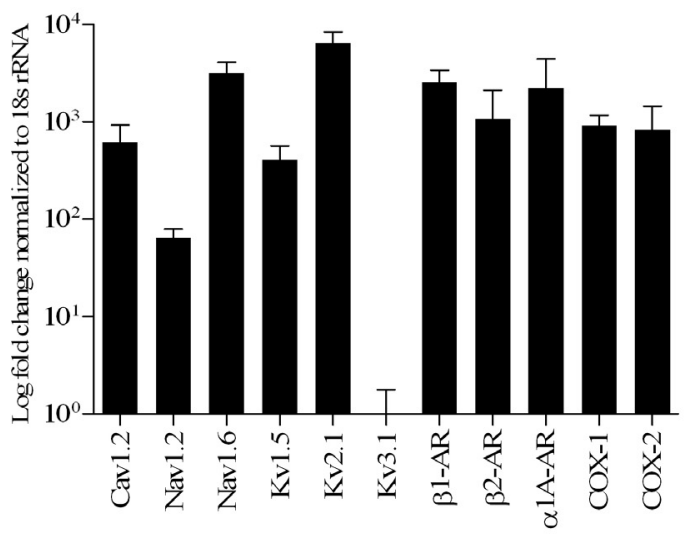

Heart

Intestine
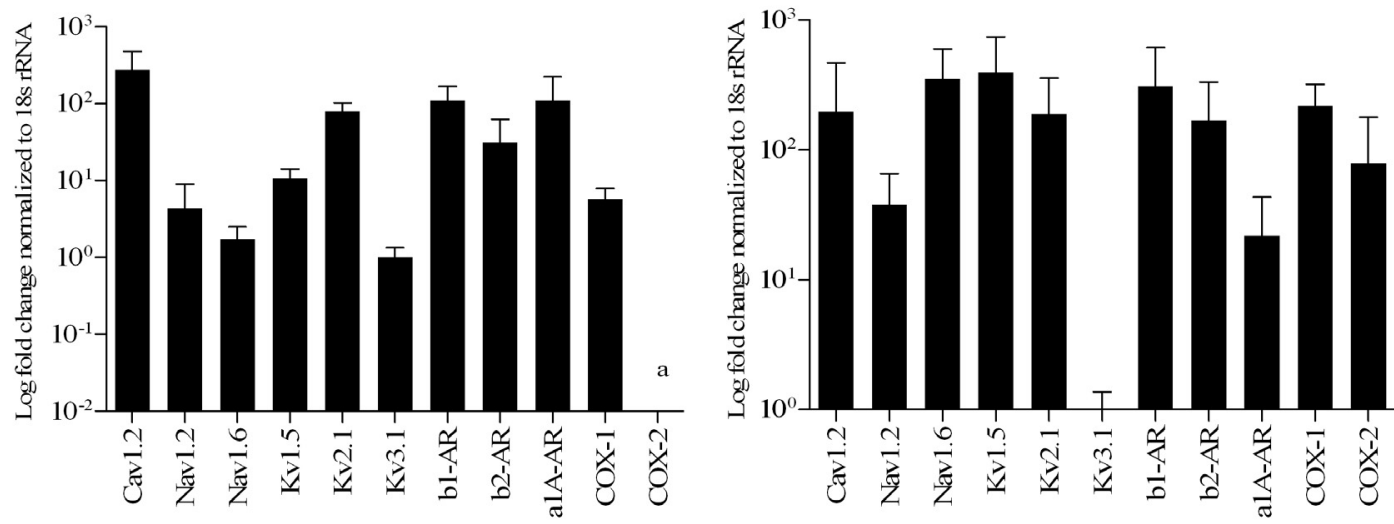

Figure 2. Constitutive expression of voltage-gated ion channels, adrenergic receptors, COX-1 and COX-2 in different rat organs ( $n=4 /$ group). Expression was determined using real time PCR in rat liver, kidney, heart and intestine. Gene expression was normalized to $18 \mathrm{~s}$ rRNA. Relative expression was determined relative to a calibrator, the gene with the lowest expression in each organ. a, was not detected in the organ.

Table 3. Tissue distribution and human orthologs of rat transporters

\begin{tabular}{|c|c|c|c|}
\hline Transporter & Human ortholog & $\begin{array}{l}\text { Constitutive gene distribution } \\
\text { (in the present study) }^{\mathrm{a}}\end{array}$ & $\begin{array}{l}\text { Tissue distribution } \\
\text { (reported elsewhere) }\end{array}$ \\
\hline \multicolumn{4}{|c|}{ Influx transporters: } \\
\hline oatp1a1 & $\begin{array}{l}\text { OATP1B1, } \\
\text { OATP1B3 }\end{array}$ & liver, kidney & $\begin{array}{l}\text { liver [76,98], kidney [98], intestine [99], brain } \\
{[100]}\end{array}$ \\
\hline oatp1a5 & & kidney & intestine [99,101], brain [99], lung [99] \\
\hline oatp1b2 & $\begin{array}{l}\text { OATP1B1, } \\
\text { OATP1B3 }\end{array}$ & liver, kidney & liver [102] \\
\hline oatp2b1 & OАТР2B1 & liver, heart, kidney, intestine & liver, intestine [32], placenta [103] \\
\hline oatp4a1 & OATP4A & kidney, intestine, liver, heart & ubiquitous [103] \\
\hline oat2 & OAT2 & liver, kidney, intestine & liver [104], kidney [105] \\
\hline oat3 & OAT3 & kidney, liver & liver [105], kidney [105], brain [106] \\
\hline oct1 & OCT1 & kidney, liver, intestine & kidney [107], intestine [107] \\
\hline \multicolumn{4}{|c|}{ Efflux transporters: } \\
\hline mdr1a & MDR1 & liver, intestine, kidney, heart & ubiquitous $[108,109]$ \\
\hline bsep & BSEP & liver, kidney & liver [110] \\
\hline mrp1 & MRP1 & kidney, heart, intestine, liver & ubiquitous [76,111] \\
\hline mrp3 & MRP3 & intestine, liver, kidney & liver[76], kidney[112], intestine[113], brain[114] \\
\hline mrp6 & MRP6 & liver, intestine, kidney & liver[76,77] \\
\hline
\end{tabular}

${ }^{a}$ mentioned in order of relative abundance; Oatp, organic anion transporter polypeptide; oat2, organic anion transporter; oct, organic cation transporter; mdr, multidrug resistance transporter; bsep, bile salts export pump; mrp, multidrug resistanceassociated protein; ${ }^{\mathrm{b}}$ uncertain. 
Liver

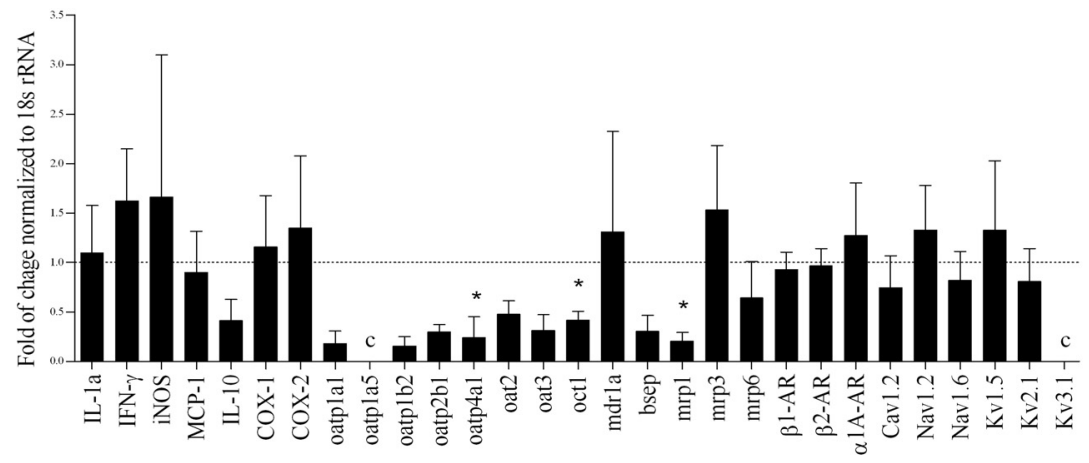

Kidney

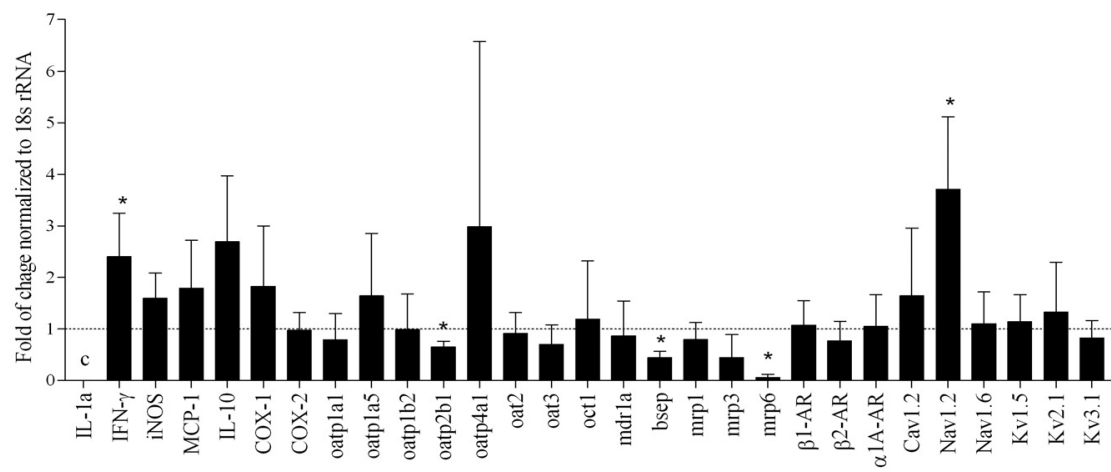

Heart
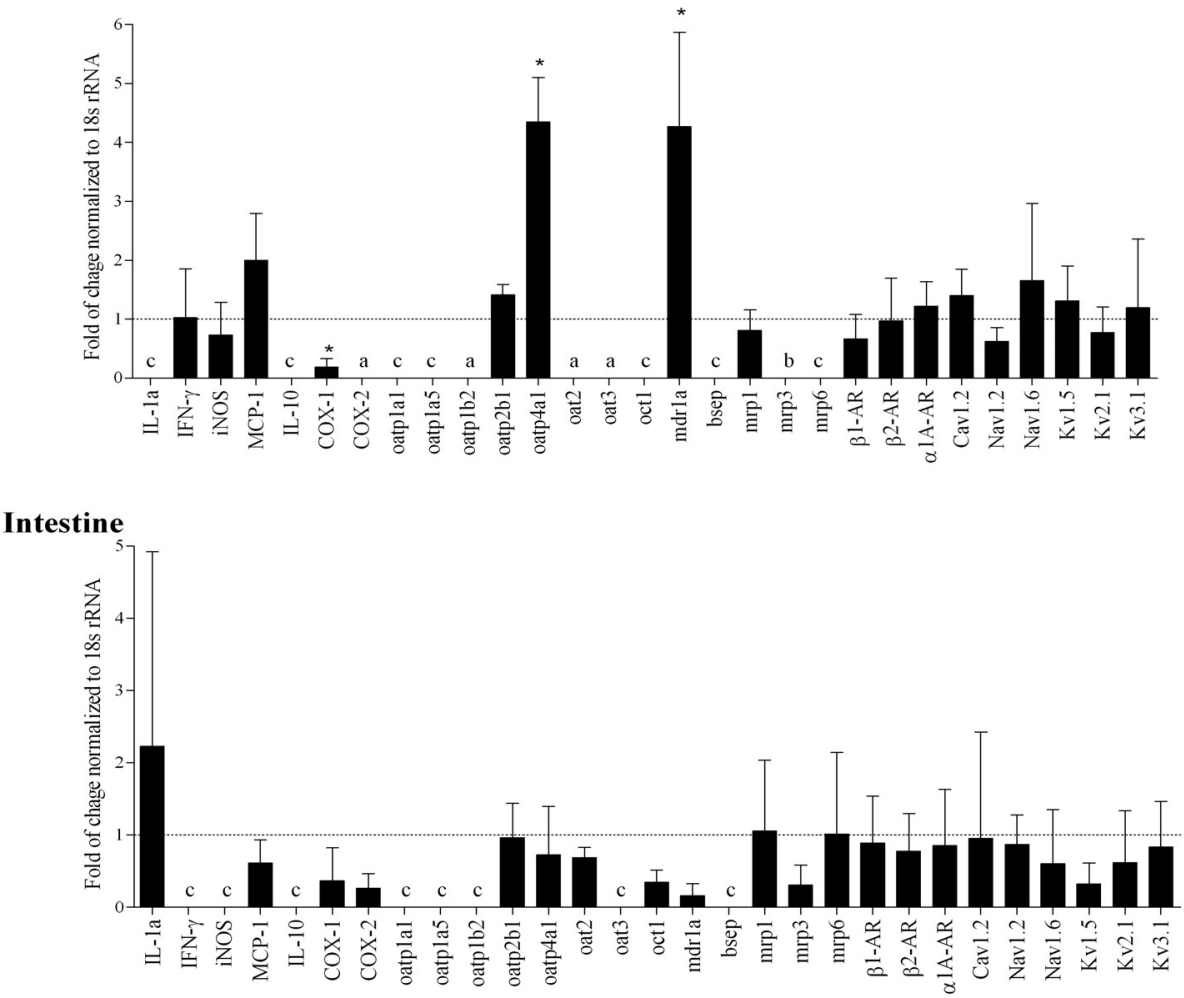

Figure 3. Effect of Adjuvant arthritis (AA) on the tested molecular targets and transporters' gene expression in different rat organs as determined using real time polymerase chain reaction (RT-PCR). Gene expression changes are represented by fold of changes of target genes in AA rats compared to Control (dotted line) ( $n=4$ /group). Gene expression was normalized to $18 \mathrm{~s}$ rRNA. ${ }^{*}, \mathrm{p}<0.05$ vs. control rats. a, was detectable in AA only; b, was detectable in Control group only; c, absent in in both healthy and AA. 
which is suggestive of a basal housekeeping function of the chemokine.

With regard to other examined inflammatory mediators (iNOS, IL-1a, INF- $\gamma$, IL-10), their presence was organ-dependant. Other observed changes remained insignificant, except for IFN- $\gamma$ in the kidney, which was significantly increased by AA. Pronounced alterations of these markers have previously been reported in the rat joints and lymphoid organs such as spleen and lymph nodes, the main sites ofinflammation in adjuvant arthritis [28]. Lack of statistically significant alterations of the examined expressions can, in part, be attributed to the variability which depends on the disease severity [20, 118].

COX-2 is an important enzyme responsible for the development of inflammation in the AA model. COX-2 (but not COX-1) expression is increased in AA rat paws and inhibition of COX-2 reverses the inflammatory response [28]. Determination of COX-1 and COX-2 genes expression in other AA rat organs has not been reported. COX-1 expression was significantly and substantially (by $80 \%$ ) reduced by inflammation only in the heart. There was a similar strong trend for intestine that did not reach significance. For the other examined organs, the present data do not suggest significant changes in either COX-1 or COX-2 gene expression in response to inflammation. Reduced expression of COX-1 has previously been observed in the hearts and lungs of rats treated with lipopolysaccharides $[29,30]$. The observed down-regulation of cardiac COX-1 may have therapeutic significance as prostaglandins are important regulatory mediators of cardiovascular function $[29,30]$. It has been found that COX-1- deficient mice have renal vasoconstriction and lower blood pressure reduction during sleep (non-dippers), a condition associated with increased risk of cardiovascular diseases in humans [31].

Oatp2b1 gene was detected in the rat heart. Cardiac oatp2b1 expression may imply its role in the cardiac uptake of digoxin, its substrate [32]. The expression of oatp2b1 was significantly reduced in the kidney of AA rats, an observation that may explain, at least in part, the previously reported reduced digoxin clearance in TNF- $\alpha$-treated mice [33].
Oatp4a1 is a thyroid hormone transporter [34]. Thyroid hormones T3 and T4 are substrates of several uptake transporters including L-amino acid transporters (LAT1, LAT2), monocarboxylate transporters (MCT8) and several OATPs [34]. Euthyroid sick syndrome is a condition characterized by altered thyroid hormone levels with normal thyroid gland function [35]. Inflammation has been implicated in the development of euthyroid sick syndrome. For example, lipopolysaccharide administration inhibited the hypothalamic pituitary-thyroid axis causing decreased TSH, T3 and T4 [36,37]. This has been explained, in part, as being due to an inflammation-induced upregulation of thyroid hormone transporters leading to increased cellular uptake of thyroid hormones. For example, MCT8 in the liver and skeletal muscles has been found to be significantly upregulated in patients with critical illness [38]. These observations are in agreement with what we have found in the AA rat hearts and the upregulation trend in the kidney. In addition, oatp4a1 was significantly downregulated in the liver of AA rats, a process that if coupled with changes to other thyroid hormone transporters, may significantly alter the hepatic uptake of thyroid hormones.

The lack of effect of inflammation on the renal oat and oct may indicate that the renal excretion of drugs that are substrates of these transporters may not be affected by inflammation. This may explain, at least in part, the lack of influence of inflammatory conditions on the clearance of renally excreted drugs such as sotalol, valsartan and losartan $[8,39,40]$. In contrast to what was observed in the kidney, oct1 is significantly downregulated in the liver of AA rats suggesting the potential reduction of the hepatic uptake of its substrates. TNF- $\alpha$ and IL- 6 have been implicated in inflammation-induced downregulation of hepatic OATs and OCTs in humans. Incubation of human hepatocytes with TNF- $\alpha$ or IL- 6 has resulted in reduced expression of OCT1 and OAT2 [41]. On the other hand, lipopolysaccharide administration in rats does not seem to alter oat 2 mRNA [42], which is suggestive of a model-dependency of the changes.

Mdrla and mdrlb are the rodent orthologs of human MDR1 (p-glycoprotein, P-gp). In the Sprague Dawley rats, mdr1a is the predominant transporter [43]. P-gp is the most studied efflux 
transporter owing to its ubiquitous distribution in most body tissues in humans and animals, its broad substrate specificity and its association with numerous clinically relevant drug interactions. Mdr1a is strategically located in different organs to facilitate specific functions. It is localized in the apical side of hepatocytes, renal tubular and intestinal cells and is responsible for the biliary secretion, tubular secretion and resisting absorption of drugs and their respective metabolites. The clinical significance of mdrla has been investigated by the use of mdrla inhibitors and mdrla knockout animals. For example, injection of radiolabeled digoxin and cyclosporine in mdrla knockout animals resulted in 20- to 50-fold increase of drug exposure [44]. The effect of inflammation on mdrla expression has been found to be model, species and organ dependent. Acute inflammatory rats models (turpentine-induced [45] and endotoxin-induced [46]) are associated with reduced expression and activity of mdrla in the rat liver, uppergastrointestinal tract and kidney. On the other hand, endotoxin-induced inflammation in mice has been associated with upregulation of renal mdrla and increased doxorubicin renal clearance [47].

Other rodent models such as renal failure [48] and colitis [49] have been found to be associated with reduced expression of P-gp in intestinal tissues. However, no change has been found in experimental cholestasis [50]. The reason for these discrepancies has been explained, in part, by the variation in inflammatory mediator profiles in different diseases and models of inflammation [51]. For example, while in vitro incubation of IL-6 with hepatocytes results in mdrla downregulation [52,53], incubation with IFN- $\gamma$ yields increased mRNA and protein expression with no change in the activity in Caco-2 cells [54]. In the present study, mdrla gene expression was not altered in the rat liver and kidney (the two major elimination organs), suggestive of unaltered biliary clearance and tubular secretion of mdrla substrates. Interestingly, mdr1a mRNA was significantly increased more than 4-fold in the hearts of AA rats, in contrast to what has been previously reported in a rat model of acute inflammation [55]. This may, at least in part, explain the observed reduced response of cardiovascular drugs in AA rats $[6,8,9,17,18,20]$. Furthermore, altered cardiac P-gp function can have a crucial role in determining drug cardiotoxicities as in the case of idarubicin [57]. However, inflammation-induced pharmacodynamic alterations caused by target channel or receptor downregulation [9], seem to have higher impact than the reduced cardiac uptake. For example, the reduced verapamil response in rats with endotoxemia has been found to be independent of its reduced uptake [56].

Generally, bsep is exclusively expressed in the liver. However, tissue distribution studies have detected its presence in the rat gut [58]. Herein, we report the expression of bsep in the rat kidney as well. However, the biological function of bsep in the kidney and intestine is not known. Lipopolysaccharide administration in rats resulted in a decline in bsep expression, an effect that can explain LPS-induced intrahepatic cholestasis [42]. In the present study, bsep is downregulated in the liver and kidney by AA. This alteration may affect bile salt transport in AA rat liver and may lead to cholestasis similar to those produced in rats by estrogen and troglitazone, which are bsep inhibitors $[59,60]$. The consequences of the reduced function of bsep are species dependent. While bsep gene mutation or inhibition in humans can lead to progressive familial intrahepatic cholestasis or drug-induced cholestasis, respectively, bsep knockout mice experienced only mild cholestasis $[61,62]$. The latter has been explained by the compensatory effects of p-glycoprotein in bile salt transport in mice [61].

Changes at the gene level may not be reflected at the level of protein or protein function. Therefore, further confirmatory experiments may be instituted to test the significance of the changes reported herein. For example, in post-myocardial injury rats, despite its protein downregulation, $\mathrm{Ca}_{\mathrm{v}} 1.2$ mRNA was not significantly different suggesting that inflammation-induced alterations are at the post-transcriptional (translational) level [63]. Similarly, the absence of a significant change in expression of $\mathrm{Ka}_{\mathrm{v}} 1.5$ may not be extrapolated at the protein level. For example, Brundel et al have found a discrepancy in $\mathrm{Ka}_{\mathrm{v}} 1.5$ gene and protein expression in the hearts of patients with atrial fibrillation. While $\mathrm{K}_{\mathrm{v}} 1.5$ mRNA did not change, its protein is downregulated [64]. Inflammation did not affect the mRNA expression of adrenergic receptors. However, it has been found that potency of propranolol (a $\beta 1$ adrenoceptor blocker) is reduced in inflammation [17,18] and this has been attributed to reduced expression of $\beta 1$ receptor proteins [65]. The reason for this discrepancy can 
be explained at the level of protein rather than the geneexpression; in other words, the effect is posttranscriptional as in the case of L-type calcium channels.

Previous reports are suggestive of the involvement of inflammatory conditions $(20,117$ $120)$ and the effect of various drugs with antiinflammatory effects $(9,17,121)$ in the outcome of pharmacotherapy at least for cardiovascular drugs. The exact mechanisms behind these involvements remain to be explored. Nevertheless, the overall

\section{REFERENCES}

1. Playfair, J.H.L., and Chain, B.M. Immunology at a glance. 8th ed. Malden, Mass.: Blackwell Pub.; 2005.

2. Renton, K.W. 2001. Alteration of drug biotransformation and elimination during infection and inflammation. Pharmacol Ther 92(2-3): 147-63.

3. Renton, K.W. 2004. Cytochrome P450 regulation and drug biotransformation during inflammation and infection. Curr Drug Metab 5(3): 235-43.

4. Aitken, A.E., Richardson, T.A., and Morgan, E.T. 2006. Regulation of drug-metabolizing enzymes and transporters in inflammation. Annu Rev Pharmacol Toxicol 46(123-49.

5. Petrovic, V., Teng, S., and Piquette-Miller, M. 2007. Regulation of drug transporters during infection and inflammation. Mol Interv 7(2): 99-111.

6. Sattari, S., Dryden, W.F., Eliot, L.A., and Jamali, F. 2003. Despite increased plasma concentration, inflammation reduces potency of calcium channel antagonists due to lower binding to the rat heart. $\mathrm{Br}$ J Pharmacol 139(5): 945-54.

7. Kulmatycki, K.M., and Jamali, F. 2005. Drug disease interactions: role of inflammatory mediators in disease and variability in drug response. $J$ Pharm Pharm Sci 8(3): 602-25.

8. Kulmatycki, K.M., Abouchehade, K., Sattari, S., and Jamali, F. 2001. Drug-disease interactions: reduced beta-adrenergic and potassium channel antagonist activities of sotalol in the presence of acute and chronic inflammatory conditions in the rat. $\mathrm{Br} J$ Pharmacol 133(2): 286-94.

9. Hanafy, S., Dagenais, N.J., Dryden, W.F., and Jamali, F. 2008. Effects of angiotensin II blockade on inflammation-induced alterations of pharmacokinetics and pharmacodynamics of calcium channel blockers. Br J Pharmacol 153(1): 90-9.

10. Kulmatycki, K.M., and Jamali, F. 2001. Therapeutic relevance of altered cytokine expression. Cytokine 14(1): 1-10. influence of inflammation on the target receptors must be kept in mind.

In conclusion, inflammation, the host defense mechanism against exogenous pathogens, alters the gene expression of some mediators and drug transporters that can influence the behavior of drugs in the body and contribute to therapeutic failure. The observed expression changes needs to be confirmed at the protein and functional level. Although preliminary, this is an exploratory investigation into the general pattern of the effect of inflammatory conditions on the status of some important proteins.

11. Piafsky, K.M., Borga, O., Odar-Cederlof, I., Johansson, C., and Sjoqvist, F. 1978. Increased plasma protein binding of propranolol and chlorpromazine mediated by disease-induced elevations of plasma alphal acid glycoprotein. $N$ Engl J Med 299(26): 1435-9.

12. Laethem, M.E., Belpaire, F.M., Wijnant, P., Rosseel, M.T., and Bogaert, M.G. 1994. Influence of endotoxin on the stereoselective pharmacokinetics of oxprenolol, propranolol, and verapamil in the rat. Chirality 6(5): 405-10.

13. Kalmovarin, N., Friedrichs, W.E., O'Brien, H.V., Linehan, L.A., Bowman, B.H., and Yang, F. 1991. Extrahepatic expression of plasma protein genes during inflammation. Inflammation 15(5): 369-79.

14. Seguin, P., Laviolle, B., Maurice, A., Leclercq, C., and Malledant, Y. 2006. Atrial fibrillation in trauma patients requiring intensive care. Intensive Care Med 32(3): 398-404.

15. Seguin, P., Signouret, T., Laviolle, B., Branger, B., and Malledant, Y. 2004. Incidence and risk factors of atrial fibrillation in a surgical intensive care unit. Crit Care Med 32(3): 722-6.

16. Okazaki, R., Iwasaki, Y.K., Miyauchi, Y., Hirayama, Y., Kobayashi, Y., Katoh, T., et al. 2009. lipopolysaccharide induces atrial arrhythmogenesis via down-regulation of L-type $\mathrm{Ca} 2+$ channel genes in rats. Int Heart $J$ 50(3): 353-63.

17. Clements, J.D., and Jamali, F. 2007. Pravastatin reverses the down-regulating effect of inflammation on beta-Adrenergic receptors: a disease-drug interaction between inflammation, pravastatin, and propranolol. Vascul Pharmacol 46(1): 52-9.

18. Guirguis, M.S., and Jamali, F. 2003. Disease-drug interaction: Reduced response to propranolol despite increased concentration in the rat with inflammation. J Pharm Sci 92(5): 1077-84.

19. Ling, S., and Jamali, F. 2005. Effect of early phase adjuvant arthritis on hepatic P450 enzymes and pharmacokinetics of verapamil: an alternative approach to the use of an animal model of inflammation for pharmacokinetic studies. Drug Metab Dispos 33(4): 579-86. 
20. Mayo, P.R., Skeith, K., Russell, A.S., and Jamali, F. 2000. Decreased dromotropic response to verapamil despite pronounced increased drug concentration in rheumatoid arthritis. Br J Clin Pharmacol 50(6): 605-13.

21. Piquette-Miller, M., and Jamali, F. 1993. Selective effect of adjuvant arthritis on the disposition of propranolol enantiomers in rats detected using a stereospecific HPLC assay. Pharm Res 10(2): 294-9.

22. Piquette-Miller, M., and Jamali, F. 1995. Influence of severity of inflammation on the disposition kinetics of propranolol enantiomers in ketoprofentreated and untreated adjuvant arthritis. Drug Metab Dispos 23(2): 240-5.

23. Hanafy, S., Tavasoli, M., and Jamali, F. 2011. Inflammation alters angiotensin converting enzymes (ACE and ACE-2) balance in rat heart. Inflammation 34(6): 609-13.

24. Joe, B., Griffiths, M.M., Remmers, E.F., and Wilder, R.L. 1999. Animal models of rheumatoid arthritis and related inflammation. Curr Rheumatol Rep 1(2): $139-48$.

25. Livak, K.J., and Schmittgen, T.D. 2001. Analysis of relative gene expression data using real-time quantitative PCR and the 2(-Delta Delta C(T)) Method. Methods 25(4): 402-8.

26. Gonzalez-Cuadrado, S., Bustos, C., Ruiz-Ortega, M., Ortiz, A., Guijarro, C., Plaza, J.J., et al. 1996. Expression of leucocyte chemoattractants by interstitial renal fibroblasts: up-regulation by drugs associated with interstitial fibrosis. Clin Exp Immunol 106(3): 518-22.

27. Satonaka, H., Suzuki, E., Nishimatsu, H., Oba, S., Takeda, R., Goto, A., et al. 2004. Calcineurin promotes the expression of monocyte chemoattractant protein-1 in vascular myocytes and mediates vascular inflammation. Circ Res 94(5): 693-700.

28. Anderson, G.D., Hauser, S.D., McGarity, K.L., Bremer, M.E., Isakson, P.C., and Gregory, S.A. 1996. Selective inhibition of cyclooxygenase (COX)-2 reverses inflammation and expression of COX-2 and interleukin 6 in rat adjuvant arthritis. $J$ Clin Invest 97(11): 2672-9.

29. Liu, S.F., Newton, R., Evans, T.W., and Barnes, P.J. 1996. Differential regulation of cyclo-oxygenase-1 and cyclo-oxygenase-2 gene expression by lipopolysaccharide treatment in vivo in the rat. Clin Sci (Lond) 90(4): 301-6.

30. Hocherl, K., Dreher, F., Kurtz, A., and Bucher, M. 2002. Cyclooxygenase-2 inhibition attenuates lipopolysaccharide-induced cardiovascular failure. Hypertension 40(6): 947-53.

31. Kawada, N., Solis, G., Ivey, N., Connors, S., Dennehy, K., Modlinger, P., et al. 2005. Cyclooxygenase-1-deficient mice have high sleepto-wake blood pressure ratios and renal vasoconstriction. Hypertension 45(6): 1131-8.
32. Nishio, T., Adachi, H., Nakagomi, R., Tokui, T., Sato, E., Tanemoto, M., et al. 2000. Molecular identification of a rat novel organic anion transporter moat1, which transports prostaglandin $\mathrm{D}(2)$, leukotriene C(4), and taurocholate. Biochem Biophys Res Commun 275(3): 831-8.

33. Kawaguchi, H., Matsui, Y., Watanabe, Y., and Takakura, Y. 2004. Effect of interferon-gamma on the pharmacokinetics of digoxin, a P-glycoprotein substrate, intravenously injected into the mouse. $J$ Pharmacol Exp Ther 308(1): 91-6.

34. Krassas, G.E., Rivkees, S.A., and Kiess, W. Diseases of the thyroid in childhood and adolescence. Basel ; New York: Karger; 2007.

35. Wartofsky, L., and Burman, K.D. 1982. Alterations in thyroid function in patients with systemic illness: the "euthyroid sick syndrome". Endocr Rev 3(2): 164-217.

36. Kondo, K., Harbuz, M.S., Levy, A., and Lightman, S.L. 1997. Inhibition of the hypothalamic-pituitarythyroid axis in response to lipopolysaccharide is independent of changes in circulating corticosteroids. Neuroimmunomodulation 4(4): 18894.

37. van der Poll, T., Endert, E., Coyle, S.M., Agosti, J.M., and Lowry, S.F. 1999. Neutralization of TNF does not influence endotoxininduced changes in thyroid hormone metabolism in humans. Am J Physiol 276(2 Pt 2): R357-62.

38. Mebis, L., Paletta, D., Debaveye, Y., Ellger, B., Langouche, L., D'Hoore, A., et al. 2009. Expression of thyroid hormone transporters during critical illness. Eur J Endocrinol 161(2): 243-50.

39. Daneshtalab, N., Lewanczuk, R.Z., Russell, A.S., and Jamali, F. 2006. Drug-disease interactions: losartan effect is not downregulated by rheumatoid arthritis. J Clin Pharmacol 46(11): 1344-55.

40. Daneshtalab, N., Lewanczuk, R.Z., Russell, A., and Jamali, F. 2004. Rheumatoid arthritis does not reduce the pharmacodynamic response to valsartan. $J$ Clin Pharmacol 44(3): 245-52.

41. Vee, M.L., Lecureur, V., Stieger, B., and Fardel, O. 2009. Regulation of drug transporter expression in human hepatocytes exposed to the proinflammatory cytokines tumor necrosis factor-alpha or interleukin6. Drug Metab Dispos 37(3): 685-93.

42. Cherrington, N.J., Slitt, A.L., Li, N., and Klaassen, C.D. 2004. Lipopolysaccharide-mediated regulation of hepatic transporter mRNA levels in rats. Drug Metab Dispos 32(15205389): 734-41.

43. Mei, Q., Richards, K., Strong-Basalyga, K., Fauty, S.E., Taylor, A., Yamazaki, M., et al. 2004. Using real-time quantitative TaqMan RT-PCR to evaluate the role of dexamethasone in gene regulation of rat P-glycoproteins mdr1a/1b and cytochrome P450 3A1/2. J Pharm Sci 93(10): 2488-96.

44. Schinkel, A.H., Wagenaar, E., van Deemter, L., Mol, C.A., and Borst, P. 1995. Absence of the 
mdr1a P-Glycoprotein in mice affects tissue distribution and pharmacokinetics of dexamethasone, digoxin, and cyclosporin A. J Clin Invest 96(4): 1698-705.

45. Piquette-Miller, M., Pak, A., Kim, H., Anari, R., and Shahzamani, A. 1998. Decreased expression and activity of P-glycoprotein in rat liver during acute inflammation. Pharm Res 15(5): 706-11.

46. Tang, W., Yi, C., Kalitsky, J., and Piquette-Miller, M. 2000. Endotoxin downregulates hepatic expression of P-glycoprotein and MRP2 in 2acetylaminofluorene-treated rats. Mol Cell Biol Res Commun 4(11170838): 90-7.

47. Hartmann, G., Vassileva, V., and Piquette-Miller, M. 2005. Impact of endotoxin-induced changes in Pglycoprotein expression on disposition of doxorubicin in mice. Drug Metab Dispos 33(15778272): 820-8.

48. Veau, C., Leroy, C., Banide, H., Auchere, D., Tardivel, S., Farinotti, R., et al. 2001. Effect of chronic renal failure on the expression and function of rat intestinal P-glycoprotein in drug excretion. Nephrol Dial Transplant 16(11477162): 1607-14.

49. Iizasa, H., Genda, N., Kitano, T., Tomita, M., Nishihara, K., Hayashi, M., et al. 2003. Altered expression and function of P-glycoprotein in dextran sodium sulfate-induced colitis in mice. $J$ Pharm Sci 92(12587118): 569-76.

50. Vos, T.A., Hooiveld, G.J., Koning, H., Childs, S., Meijer, D.K., Moshage, H., et al. 1998. Upregulation of the multidrug resistance genes, Mrp1 and Mdrlb, and down-regulation of the organic anion transporter, Mrp2, and the bile salt transporter, Spgp, in endotoxemic rat liver. Hepatology 28(6): 1637-44.

51. Fernandez, C., Buyse, M., German-Fattal, M., and Gimenez, F. 2004. Influence of the proinflammatory cytokines on P-glycoprotein expression and functionality. $J$ Pharm Pharm Sci 7(3): 359-71.

52. Hartmann, G., Kim, H., and Piquette-Miller, M. 2001. Regulation of the hepatic multidrug resistance gene expression by endotoxin and inflammatory cytokines in mice. Int Immunopharmacol 1(11360920): 189-99.

53. Sukhai, M., Yong, A., Kalitsky, J., and PiquetteMiller, M. 2000. Inflammation and interleukin-6 mediate reductions in the hepatic expression and transcription of the mdrla and mdrlb Genes. Mol Cell Biol Res Commun 4(11409920): 248-56.

54. Belliard, A.M., Lacour, B., Farinotti, R., and Leroy, C. 2004. Effect of tumor necrosis factor-alpha and interferon-gamma on intestinal P-glycoprotein expression, activity, and localization in Caco-2 cells. $J$ Pharm Sci 93(6): 1524-36.

55. Wang, J.-H., Scollard, D.A., Teng, S., Reilly, R.M., and Piquette-Miller, M. 2005. Detection of Pglycoprotein activity in endotoxemic rats by $99 \mathrm{mTc}$ - sestamibi imaging. J Nucl Med 46(16157538): 153745.

56. Sermsappasuk, P., Abdelrahman, O., and Weiss, M. 2008. Cardiac pharmacokinetics and inotropic response of verapamil in rats with endotoxemia. $J$ Pharm Sci 97(7): 2798-804.

57. Kang, W., and Weiss, M. 2001. Influence of Pglycoprotein modulators on cardiac uptake, metabolism, and effects of idarubicin. Pharm Res 18(11): 1535-41.

58. Torok, M., Gutmann, H., Fricker, G., and Drewe, J. 1999. Sister of P-glycoprotein expression in different tissues. Biochem Pharmacol 57(7): 833-5.

59. Stieger, B., Fattinger, K., Madon, J., Kullak-Ublick, G.A., and Meier, P.J. 2000. Drug- and estrogeninduced cholestasis through inhibition of the hepatocellular bile salt export pump (Bsep) of rat liver. Gastroenterology 118(2): 422-30.

60. Funk, C., Ponelle, C., Scheuermann, G., and Pantze, M. 2001. Cholestatic potential of troglitazone as a possible factor contributing to troglitazone-induced hepatotoxicity: in vivo and in vitro interaction at the canalicular bile salt export pump (Bsep) in the rat. Mol Pharmacol 59(3): 627-35.

61. Wang, R., Chen, H.L., Liu, L., Sheps, J.A., Phillips, M.J., and Ling, V. 2009. Compensatory role of Pglycoproteins in knockout mice lacking the bile salt export pump. Hepatology 50(3): 948-56.

62. Lam, P., Soroka, C.J., and Boyer, J.L. 2010. The bile salt export pump: clinical and experimental aspects of genetic and acquired cholestatic liver disease. Semin Liver Dis 30(2): 125-33.

63. Hanafy, S., El-Kadi, A.O., and Jamali, F. 2010. Drug-disease interaction: reduced verapamil response in isoproterenol-induced myocardial injury in rats. Pharmacology 86(4): 196-202.

64. Brundel, B.J., Van Gelder, I.C., Henning, R.H., Tuinenburg, A.E., Wietses, M., Grandjean, J.G., et al. 2001. Alterations in potassium channel gene expression in atria of patients with persistent and paroxysmal atrial fibrillation: differential regulation of protein and mRNA levels for $\mathrm{K}+$ channels. $J \mathrm{Am}$ Coll Cardiol 37(3): 926-32.

65. Clements, J.D., and Jamali, F. 2009. Norepinephrine transporter is involved in down-regulation of beta1adrenergic receptors caused by adjuvant arthritis. $J$ Pharm Pharm Sci 12(3): 337-45.

66. Kikuchi, A., Nozawa, T., Wakasawa, T., Maeda, T., and Tamai, I. 2006. Transporter-mediated intestinal absorption of fexofenadine in rats. Drug Metab Pharmacokinet 21(4): 308-14.

67. Evers, R., and Chu, X.Y. 2008. Role of the murine organic anion-transporting polypeptide $1 \mathrm{~b} 2$ (Oatp1b2) in drug disposition and hepatotoxicity. Mol Pharmacol 74(2): 309-11.

68. Zaher, H., zu Schwabedissen, H.E., Tirona, R.G., Cox, M.L., Obert, L.A., Agrawal, N., et al. 2008. Targeted disruption of murine organic anion- 
transporting polypeptide $1 \mathrm{~b} 2$ (Oatp1b2/Slco1b2) significantly alters disposition of prototypical drug substrates pravastatin and rifampin. Mol Pharmacol 74(2): 320-9.

69. Ayrton, A., and Morgan, P. 2001. Role of transport proteins in drug absorption, distribution and excretion. Xenobiotica 31(8-9): 469-97.

70. Enomoto, A., Takeda, M., Tojo, A., Sekine, T., Cha, S.H., Khamdang, S., et al. 2002. Role of organic anion transporters in the tubular transport of indoxyl sulfate and the induction of its nephrotoxicity. $J \mathrm{Am}$ Soc Nephrol 13(7): 1711-20.

71. Stieger, B., Meier, Y., and Meier, P.J. 2007. The bile salt export pump. Pflugers Arch 453(5): 611-20.

72. Hirano, M., Maeda, K., Hayashi, H., Kusuhara, H., and Sugiyama, Y. 2005. Bile salt export pump (BSEP/ABCB11) can transport a nonbile acid substrate, pravastatin. J Pharmacol Exp Ther 314(2): 876-82.

73. Lecureur, V., Sun, D., Hargrove, P., Schuetz, E.G., Kim, R.B., Lan, L.B., et al. 2000. Cloning and expression of murine sister of P-glycoprotein reveals a more discriminating transporter than MDR1/Pglycoprotein. Mol Pharmacol 57(1): 24-35.

74. Ho, R.H., and Kim, R.B. 2005. Transporters and drug therapy: implications for drug disposition and disease. Clin Pharmacol Ther 78(3): 260-77.

75. Cole, S.P., Bhardwaj, G., Gerlach, J.H., Mackie, J.E., Grant, C.E., Almquist, K.C., et al. 1992. Overexpression of a transporter gene in a multidrugresistant human lung cancer cell line. Science 258(5088): 1650-4.

76. Cao, J., Stieger, B., Meier, P.J., and Vore, M. 2002. Expression of rat hepatic multidrug resistanceassociated proteins and organic anion transporters in pregnancy. Am J Physiol Gastrointest Liver Physiol 283(3): G757-66.

77. Madon, J., Hagenbuch, B., Landmann, L., Meier, P.J., and Stieger, B. 2000. Transport function and hepatocellular localization of mrp6 in rat liver. $\mathrm{Mol}$ Pharmacol 57(3): 634-41.

78. Bodi, I., Mikala, G., Koch, S.E., Akhter, S.A., and Schwartz, A. 2005. The L-type calcium channel in the heart: the beat goes on. J Clin Invest 115(12): 3306-17.

79. McDonough, S.I. Calcium channel pharmacology. New York: Kluwer Academic/Plenum Publishers; 2004.

80. Catterall, W.A., Goldin, A.L., and Waxman, S.G. 2005. International Union of Pharmacology. XLVII. Nomenclature and structure-function relationships of voltage-gated sodium channels. Pharmacol Rev 57(4): 397-409.

81. Snyders, D.J., Tamkun, M.M., and Bennett, P.B. 1993. A rapidly activating and slowly inactivating potassium channel cloned from human heart. Functional analysis after stable mammalian cell culture expression. J Gen Physiol 101(4): 513-43.
82. Brunton, L.L., Lazo, J.S., and Parker, K.L. Goodman \& Gilman's The Pharmacological Basis of Therapeutics. 11th ed: The McGraw-Hill Companies; 2006.

83. Lalevee, N., Rebsamen, M.C., Barrere-Lemaire, S., Perrier, E., Nargeot, J., Benitah, J.P., et al. 2005. Aldosterone increases T-type calcium channel expression and in vitro beating frequency in neonatal rat cardiomyocytes. Cardiovasc Res 67(2): 216-24.

84. Koch, W.J., Ellinor, P.T., and Schwartz, A. 1990. cDNA cloning of a dihydropyridine-sensitive calcium channel from rat aorta. Evidence for the existence of alternatively spliced forms. $J$ Biol Chem 265(29): 17786-91.

85. Sato, S., Nomura, S., Kawano, F., Tanihata, J., Tachiyashiki, K., and Imaizumi, K. 2008. Effects of the beta2-agonist clenbuterol on beta1- and beta2adrenoceptor mRNA expressions of rat skeletal and left ventricle muscles. J Pharmacol Sci 107(4): 393400.

86. Marti, D., Miquel, R., Ziani, K., Gisbert, R., Ivorra, M.D., Anselmi, E., et al. 2005. Correlation between mRNA levels and functional role of alpha1adrenoceptor subtypes in arteries: evidence of alpha1L as a functional isoform of the alpha1Aadrenoceptor. Am J Physiol Heart Circ Physiol 289(5): H1923-32.

87. Van Wart, A., and Matthews, G. 2006. Expression of sodium channels Nav1.2 and Nav1.6 during postnatal development of the retina. Neurosci Lett 403(3): 315-7.

88. Wu, C., Hayama, E., Imamura, S., Matsuoka, R., and Nakanishi, T. 2007. Developmental changes in the expression of voltage-gated potassium channels in the ductus arteriosus of the fetal rat. Heart Vessels 22(1): 34-40.

89. Zhu, L.J., and Altmann, S.W. 2005. mRNA and 18S-RNA coapplication-reverse transcription for quantitative gene expression analysis. Anal Biochem 345(1): 102-9.

90. St-Pierre, M.V., Stallmach, T., Freimoser Grundschober, A., Dufour, J.F., Serrano, M.A., Marin, J.J., et al. 2004. Temporal expression profiles of organic anion transport proteins in placenta and fetal liver of the rat. Am J Physiol Regul Integr Comp Physiol 287(6): R1505-16.

91. Wood, M., Ananthanarayanan, M., Jones, B., Wooton-Kee, R., Hoffman, T., Suchy, F.J., et al. 2005. Hormonal regulation of hepatic organic anion transporting polypeptides. Mol Pharmacol 68(1): 218-25.

92. Shi, L.Z., Li, G.J., Wang, S., and Zheng, W. 2008. Use of Z310 cells as an in vitro blood-cerebrospinal fluid barrier model: tight junction proteins and transport properties. Toxicol In Vitro 22(1): 190-9.

93. Denk, G.U., Soroka, C.J., Mennone, A., Koepsell, H., Beuers, U., and Boyer, J.L. 2004. Down- 
regulation of the organic cation transporter 1 of rat liver in obstructive cholestasis. Hepatology 39(5): $1382-9$.

94. Wang, J., Kannan, S., Li, H., and Khan, M.F. 2005. Cytokine gene expression and activation of NFkappa B in aniline-induced splenic toxicity. Toxicol Appl Pharmacol 203(1): 36-44.

95. Steinmetz, O.M., Sadaghiani, S., Panzer, U., Krebs, C., Meyer-Schwesinger, C., Streichert, T., et al. 2007. Antihypertensive therapy induces compartment-specific chemokine expression and a Th1 immune response in the clipped kidney of Goldblatt hypertensive rats. Am J Physiol Renal Physiol 292(2): F876-87.

96. Long, J.P., Tong, H.H., Shannon, P.A., and DeMaria, T.F. 2003. Differential expression of cytokine genes and inducible nitric oxide synthase induced by opacity phenotype variants of Streptococcus pneumoniae during acute otitis media in the rat. Infect Immun 71(10): 5531-40.

97. Joseph, S.A., Lynd-Balta, E., O'Banion, M.K., Rappold, P.M., Daschner, J., Allen, A., et al. 2006. Enhanced cyclooxygenase-2 expression in olfactorylimbic forebrain following kainate-induced seizures. Neuroscience 140(3): 1051-65.

98. Bergwerk, A.J., Shi, X., Ford, A.C., Kanai, N., Jacquemin, E., Burk, R.D., et al. 1996. Immunologic distribution of an organic anion transport protein in rat liver and kidney. Am J Physiol 271(2 Pt 1): G231-8.

99. Walters, H.C., Craddock, A.L., Fusegawa, H., Willingham, M.C., and Dawson, P.A. 2000. Expression, transport properties, and chromosomal location of organic anion transporter subtype 3. Am J Physiol Gastrointest Liver Physiol 279(6): G1188200.

100. Jacquemin, E., Hagenbuch, B., Stieger, B., Wolkoff, A.W., and Meier, P.J. 1994. Expression cloning of a rat liver $\mathrm{Na}(+)$-independent organic anion transporter. Proc Natl Acad Sci U S A 91(1): 133-7.

101. Tani, T., Gram, L.K., Arakawa, H., Kikuchi, A., Chiba, M., Ishii, Y., et al. 2008. Involvement of organic anion transporting polypeptide 1a5 (Oatp1a5) in the intestinal absorption of endothelin receptor antagonist in rats. Pharm Res 25(5): 108591.

102. Fujiyama, N., Shitara, Y., Ito, K., Masubuchi, Y., and Horie, T. 2007. Down-regulation of hepatic transporters for BSP in rats with indomethacininduced intestinal injury. Biol Pharm Bull 30(3): $556-61$.

103. Hagenbuch, B., and Meier, P.J. 2004. Organic anion transporting polypeptides of the OATP/ SLC21 family: phylogenetic classification as OATP/ SLCO superfamily, new nomenclature and molecular/functional properties. Pflugers Arch 447(5): 653-65.
104.Simonson, G.D., Vincent, A.C., Roberg, K.J., Huang, Y., and Iwanij, V. 1994. Molecular cloning and characterization of a novel liver-specific transport protein. J Cell Sci 107 ( Pt 4)(1065-72.

105. Kobayashi, Y., Hirokawa, N., Ohshiro, N., Sekine, T., Sasaki, T., Tokuyama, S., et al. 2002. Differential gene expression of organic anion transporters in male and female rats. Biochem Biophys Res Commun 290(1): 482-7.

106. Nagata, Y., Kusuhara, H., Endou, H., and Sugiyama, Y. 2002. Expression and functional characterization of rat organic anion transporter 3 (rOat3) in the choroid plexus. Mol Pharmacol 61(5): 982-8.

107.Grundemann, D., Gorboulev, V., Gambaryan, S., Veyhl, M., and Koepsell, H. 1994. Drug excretion mediated by a new prototype of polyspecific transporter. Nature 372(6506): 549-52.

108.Ando, H., Nishio, Y., Ito, K., Nakao, A., Wang, L., Zhao, Y.L., et al. 2001. Effect of endotoxin on Pglycoprotein-mediated biliary and renal excretion of rhodamine-123 in rats. Antimicrob Agents Chemother 45(11709325): 3462-7.

109.Goralski, K.B., Hartmann, G., Piquette-Miller, M., and Renton, K.W. 2003. Downregulation of mdr1a expression in the brain and liver during CNS inflammation alters the in vivo disposition of digoxin. Br J Pharmacol 139(12746221): 35-48.

110.Childs, S., Yeh, R.L., Georges, E., and Ling, V. 1995. Identification of a sister gene to Pglycoprotein. Cancer Res 55(10): 2029-34.

111.Nunoya, K., Grant, C.E., Zhang, D., Cole, S.P., and Deeley, R.G. 2003. Molecular cloning and pharmacological characterization of rat multidrug resistance protein 1 (mrp1). Drug Metab Dispos 31(8): 1016-26.

112.Hirohashi, T., Suzuki, H., Ito, K., Ogawa, K., Kume, K., Shimizu, T., et al. 1998. Hepatic expression of multidrug resistance-associated protein-like proteins maintained in eisai hyperbilirubinemic rats. $\mathrm{Mol}$ Pharmacol 53(6): 1068-75.

113.Rost, D., Mahner, S., Sugiyama, Y., and Stremmel, W. 2002. Expression and localization of the multidrug resistance-associated protein 3 in rat small and large intestine. Am J Physiol Gastrointest Liver Physiol 282(4): G720-6.

114. Hirrlinger, J., Konig, J., and Dringen, R. 2002. Expression of mRNAs of multidrug resistance proteins (Mrps) in cultured rat astrocytes, oligodendrocytes, microglial cells and neurones. $J$ Neurochem 82(3): 716-9.

115.Olson, T., Alekseev, A., Liu, X., Park, S., Zingman, L., Bienegraeber, M., et al. 2006. Kv1.5 channelopathy due to KCNA5 loss-of-function mutation causes human atrial fibrillation. Hum $\mathrm{Mol}$ Genet 15(14):2185-2191

116.Archer, S., Souil, E., Dinh-Xuan, A., Schremmer, B., Mercier, J., El Yaagoubi et al. 1998. 
Identification of the role of voltage-gated $\mathrm{K} 1$ channels, Kv1.5 andKv2.1, in hypoxic pulmonary vasoconstriction and control of resting membrane potential in rat pulmonary artery myocytes. $J$ Clin Invest 101:2319-2330.

117.Jamali, F., Kunz-Dober, C.M. 1999. Pain-mediated altered absorption and metabolism of ibuprofen: an explanation for decreased serum enantiomer concentration after dental surgery. $\mathrm{Br} \quad \mathrm{J}$ Clin Pharmacol 47, 391-396.

118.Sanaee, F., Clements, J.D., Waugh, A.W., Fedorak, R.N., Lewanczuk, R., Jamali, F. 2011. Drug-disease interaction: Crohn's disease elevates verapamil plasma concentrations but reduces response to the drug proportional to disease activity. $\mathrm{Br} J$ Cllin Pharmacol 72: 787-797.

119.Hanafy, S., Pinsk, M., Jamali, F. 2009. Effect of obesity on response to cardiovascular drugs in pediatric patients with renal disease. Pediatr Nephrol 24:815-821.

120.Biasucci, L.M., Liuzzo, G., Crea, F. 2008. Acute coronary syndromes: to CRP or not to CRP? $\mathrm{J} \mathrm{Am}$ Coll Cardiol 51:2339-46.

121.Davies, N.M., Longstreth, J., Jamali, F. 2001. Misoprostol therapeutics revisited. Pharmacotherapy 21:60-73. 